\title{
Impact of Inlet Drying Temperature in Endless Chain Pressure Dryers on the Quality Characteristics of Leafy Type of Tea Produced Using Different Leaf Standards
}

\author{
S. Kavish ${ }^{1}$, W. S. Botheju ${ }^{2}$, C. S. De Silva ${ }^{1 *}$ \\ ${ }^{1}$ Department of Agricultural and Plantation Engineering, The Open \\ University of Sri Lanka. \\ ${ }^{2}$ Tea Research Institute of Sri Lanka, Talawakelle
}

\section{Abstract}

This study was carried out to investigate the appropriate higher inlet drying temperatures in Endless Chain Pressure (ECP) dryers to assess the improvement of quality characteristic of Orthodox type of tea of seven grades (OP, OP1, PEKOE, FBOPF, FBOP, FBOPF1 and OPA) produced using three different standards of leaves. Selected Leaf standards were $40 \%, 50 \%$, and $60 \%$ of good leaves (fine plucking of two leaves and a bud). Two different drying temperatures, $205 \circ \mathrm{F}$ as the control and $230 \circ \mathrm{F}$ as the treatment, selected for this study. Pilot scale Orthodox rollers with a capacity of $15 \mathrm{~kg}$ withered leaves were used to undertake Pure Orthodox manufacturing process. Experiment was conducted in triplicate for each leaf standard at two different drying temperatures. Dried tea samples were separated into seven grades namely OP, OP1, PEKOE, FBOPF, FBOP, FBOPF1 and OPA. Graded tea samples were organoleptically assessed for their liquoring properties such as infused leaf color, liquor color and strength, quality and the appearance of graded tea by professional tea tasters' in Colombo. Results revealed that there was no significant difference in liquoring properties of made tea produced at higher drying inlet temperature against dryer temperature of $205 \mathrm{o}$ for three different standards of leaf. It indicates that higher inlet drying temperature does not influence the overall quality of the liquor. However, a trend was observed that tea produced with $60 \%$ good leaves, gave better

\footnotetext{
*Correspondence should be addressed to Prof. C. S. De Silva, Department of Agricultural and Plantation Engineering, Faculty of Engineering Technology, The Open University of Sri Lanka (Email: csdes@ou.ac.lk)
} 
liquoring properties at $205 \mathrm{oF}$ than the higher inlet temperature. Therefore, when there is $60 \%$ good leaves, maintaining higher inlet temperature for drying has not gained any advantage to produce tea with better liquor quality. The appearance of OPA, PEKOE, FBOP and FBOPF grades showed a significant difference when there is only $40 \%$ good leaves at higher inlet temperature of $230 \mathrm{oF}$. The appearance of OP, OP1 and FBOPF1 grades did not show a significant difference at higher inlet temperature for all three leaf standards of $40 \%, 50 \%$ and $60 \%$ good leaves. Therefore, better appearance can be achieved by maintaining higher inlet temperature of $230^{\circ} \mathrm{F}$ when there is only $40 \%$ good leaves.

Keywords: Endless Chain Pressure dryer, infused leaf, Leaf standard, liquor color and strength, pilot scale manufacture.

\section{Introduction}

Tea estates are ranked according to the net sale monthly average price and to date average price. Some estates in the same region are at the top of the ranking while others are in the middle or at the bottom due to the price variation of their net sale average (NSA). One reason for the demand for their tea grades may be good manufacturing practices in addition to maintaining better leaf standards. Leaf standards mean the percentage of good leaves (fine plucking). The leaf standard varies from estate to estate based on the harvesting policy adopted. Green leaf is the raw material for black tea processing and it is important to have a good quality black tea. Good leaf is named as "Tender leaf" that consists of two leaves and the bud (Fine plucking) (Tubb, 1999). Hundred percent good leaves are not practicable. Therefore, Tea Research Institute (TRI) recommends $60-65 \%$ of good leaves (on count basis) to ensure better quality of the end product (Robert, 2008). Also product consistency has a significant impact on achieving better colour and taste (Samaraweera and Ziyad, 2008). In tea drying inlet temperature of $190-200{ }^{\circ} \mathrm{F}$ and exhaust temperature of $120-130{ }^{\circ} \mathrm{F}$ represent the normal range of temperature used in Endless Chain Pressure (ECP) dryer (Jayaratnam and Kirthisinghe, 1974). Most of the low country tea producers increase the drying temperature higher than the 
recommended level $\left(190^{\circ} \mathrm{F}\right)$ with a view to improve the appearance/ blackness. However, they do not have a clear idea about the potential impact on liquoring properties of made tea while increasing inlet temperature higher than the recommended level. In this study, an attempt was made to find out whether there is a correlation between the leaf standards $(40 \%, 50 \%$ and $60 \%$ good leaves) and inlet drying temperature levels for seven tea grades. Further, attempt was also made to determine/compare final made tea quality at both higher inlet temperatures and at recommended drying temperature levels. Objective of this experiment was to study the impact of different inlet temperatures of the ECP dryer on the quality of made tea of seven grades produced from different leaf standards and to assess the liquoring properties and appearance of leafy type of graded tea Organoleptically.

\section{Methodology}

The experiment was conducted at Processing and Technology Division, Tea Research Institute of Sri Lanka at St. Coombs Estate, Talawakelle. The Agro ecological zone of the area is WU3. Tea leaves used for this experiment were collected from factory withering troughs, which were dominated by shoots of TRI 2025 cultivar. Leaf standard of normal estate plucking policy varies from day to day. Three different leaf standards were selected for this study which was $40 \%, 50 \%$ and $60 \%$ good leaves (fine plucking). Fine plucking means two leaves and a bud which gives rise to bright red liquor both in plain and milky teas (Naheed et al, 2007). Before the leaves were collected for the experiment, and leaf standard was calculated by picking leaf samples randomly from the trough and determining the good leaf percentage. If the percentage of the leaves was similar to the experimental standard, trough was selected for the experiment. In this study, $230{ }^{\circ} \mathrm{F}$ inlet drying air temperature was selected as the treatment while $205{ }^{\circ} \mathrm{F}$ as the control for ECP dryer. The reason for selecting $230{ }^{\circ} \mathrm{F}$ was that most of the low country tea producers are using this temperature. Six treatment combinations are shown in the Table. 1. 
Table 1. Treatment plan of the experiment

\begin{tabular}{|c|c|c|c|}
\hline & \multicolumn{3}{|c|}{ Leaf standard-Good leaves (\%) } \\
\hline $\begin{array}{c}\text { Inlet } \\
\text { Temperature }\end{array}$ & $40(\mathrm{~L} 1)$ & $50(\mathrm{~L} 2)$ & 60 (L3) \\
\hline $205^{\circ} \mathrm{F} \quad(\mathrm{T} 1)$ & $\mathrm{L} 1 \mathrm{~T} 1$ & L2T1 & L3T1 \\
\hline $230^{\circ} \mathrm{F} \quad(\mathrm{T} 2)$ & $\mathrm{L} 1 \mathrm{~T} 2$ & $\mathrm{~L} 2 \mathrm{~T} 2$ & $\mathrm{~L} 2 \mathrm{~T} 2$ \\
\hline
\end{tabular}

\section{Types of Plucking}

Usually shoots with two leaves and the bud are fine plucking. Tea shoots with more than two leaves during the low cropping season is considered as coarse plucking. However, shoots with three leaves and a bud are also accepted as fine plucking during the high cropping season due to the tenderness of the third leaf (Botheju, 2001). The factory trough consisted of a mixture of shoots; bud and two leaves, bud and three leaves, soft banji bud (undeveloped) with two tender leaves, (described as fine leaf plucking) mother leaves/coarse leaves and damaged leaves, which are considered as fish leaf plucking or hard plucking (Figure 1).

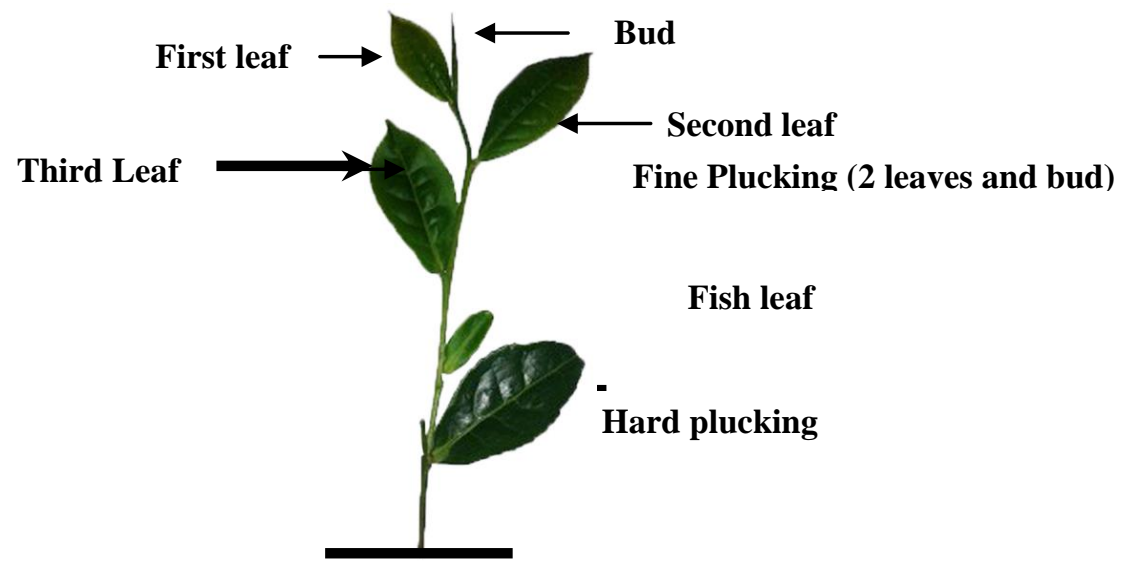

Figure 1. Tea leaves (Tender leaves and coarse leaves)

\section{Experimental Design}

Experiment was carried out as a 2 factor factorial design (i.e. three different leaf standards $(40 \%, 50 \%$ and $60 \%$ good leaves of fine plucking) and two drying inlet temperatures $\left(205^{\circ} \mathrm{F}\right.$ and $\left.230^{\circ} \mathrm{F}\right)$ with 
three replicates per each treatment combinations.

\section{Procedure in Made Tea}

Plucked leaves were withered on factory withering troughs for 12-16 hours until its moisture was reduced to 55-57\% (Roberts, 2008). Withered leaf samples $(50 \mathrm{~g})$ drawn from withering trough in duplicate were used to test moisture content. After completion of the withering process, withered leaves were processed separately for treatment samples and control samples using set of medium sized pilot scale manufacturing machines available at St. Coombs factory. In the process of manufacturing, weighed $(15 \mathrm{~kg})$ withered leaves were rolled using single action pilot scale Orthodox roller. After rolling for $30 \mathrm{~min}$ period, rolled leaves were discharged and separated to even size particles (dhool) using pilot scale oscillatory type roll breaker. No 4 mesh fixed to roll breaker was used to separate tea dhool. The rolling operation was continued until big bulk percentage reached to about $32 \%$. Each dhool (1st and $2^{\text {nd }}$ dhool) from the treatment and control samples were mixed and spread on clean fermenting trays separately for about $5 \mathrm{~cm}$ height to facilitate fermentation. The humidity level of the fermenting area was maintained using humidifiers in order to keep hygrometric difference below $3{ }^{\circ} \mathrm{F}$ (Samaraweera, 1986). After about a 3 hour fermentation period, fermented dhools were subjected for drying using ECP dryer.

Hot air required for drying was generated using electrical heating element that has five different power ratings. In this study, drying inlet temperature of air selected for treatment sample was $230{ }^{\circ} \mathrm{F}$ whilst for the control sample it was $205^{\circ} \mathrm{F}$. Exhaust air temperature of the dryer outlet was maintained at $135^{\circ} \mathrm{F}$. The residence time was approximately $21 \mathrm{~min}$. Dried tea from treatment and control samples were graded using hand sieves. The sieve sizes such as No.4, No.5, No.8, No.10, No.12, and No.16 were used to obtain seven different grades; OPA, OP, OP1, PEKOE, FBOP, FBOPF1 and FBOPF (Figure 

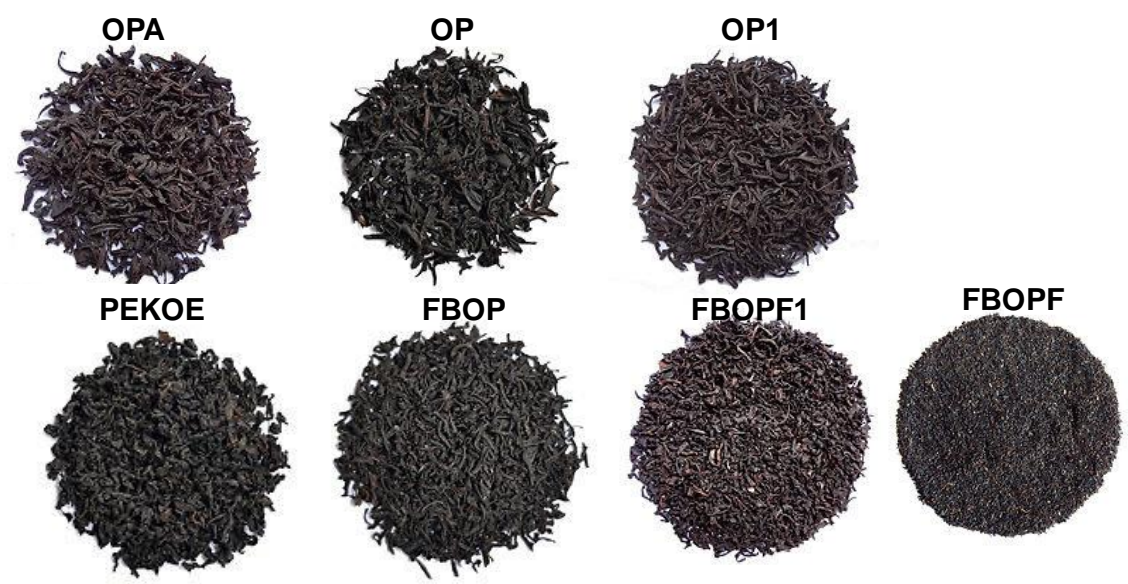

Used sieve numbers for grading - No.4, No.6, No.8, No.10, No.12 and No.16

Figure 2. Different grades of Tea

\section{Tea Tasting}

Graded tea samples were sent for tea tasters' evaluation in Colombo and assessed for organoleptic qualities or liquoring properties based on the characters such as infused leaf color, tea liquor color, strength, quality and flavor. Liquoring properties and appearance of 126 tea samples produced were evaluated by specialized tea tasters.

\section{Liquoring Properties}

Sensory evaluation of tea quality depends on visual observation, smelling and tasting senses by tea evaluation specialists to determine the tea quality. In this method the taster judges the quality parameters by assessing the physical attributes of liquor and infused leaf of the tea. Based on the tasters' evaluation marks, Overall Quality was calculated by using different liquoring properties such as infused leaf colour, liquor colour and strength, quality and flavor for three different leaf standards $(40 \%, 50 \%$ and $60 \%$ good leaves) of individual grades. 


\section{- Infused Leaf}

Analyzing the infused leaf allows the taster to set certain impressions of the tea before tasting. The most important part of a taster's palate is a sense of smell. Infused leaf can inform smells indicating problems in production, storage or the presence of certain regional characteristics. Bright appearance indicates bright liquors. Lack of brightness usually denotes poor tea.

\section{- Colour}

Liquor colour is one of the most important quality parameters of tea. Liquor colour is considered the qualifying factor for quality. The variation of liquor colour from greenish to yellow to deep brown or blackish brown is mainly due to the extent of thevafalvins (TF) and thearubigins (TR) formation during manufacturing of the tea. The perfect colour of infused leaf is bright copper or red (Biswas, 2014).

\section{- Strength}

This denotes substance in liquor and is generally described by a qualifying adjective such as "strong", "very strong" or "fair strength". Liquor colour is a good guide to strength; pale and light looking tea liquors generally have less strength than coloury liquors. Within grades from the same estate, strength normally follows colour and the colouriest grades, usually Dusts are the strongest.

\section{- Quality}

This is the essential characteristic of a good tea and is an impression derived from the palate when tea liquor is tasted. Although it is not possible to explain what quality in tea actually tastes like, it is possible to say that common, coarse and plain liquors are severely lacking in this quality.

\section{- Flavor}

Flavor is a most noticeable aroma, which is sensed through the mouth as different from the nose. The most delicate flavors are found on estates at high elevations. Sri Lankan teas from high elevations are popular for their fine flavor liquors, with seemingly limitless flavors. Researchers have identified five flavors that cause taste sensation (sweet, bitter, sour, salty, and savory). But tasting is actually much more complex. 


\section{- Overall quality}

The term 'overall quality' is used as a description of all the characters of tea by which it is judged on its market value. Overall quality means the summation of the desirable attributes of the characters like infused leaf, colour, strength, quality and flavor in this experiment.

\section{Results and Discussion}

\section{Liquoring Properties}

No significant difference was observed for overall quality of OP graded tea samples produced by treatment at $230{ }^{\circ} \mathrm{F}$ inlet temperature and control at $205{ }^{\circ} \mathrm{F}$ inlet temperature for three different leaf standards of $40 \%, 50 \%$ and $60 \%$ good leaves (Figure 3 ). However, in OP grade of $60 \%$ good leaves, there was an increase in overall quality at $205{ }^{\circ} \mathrm{F}$ compared with $230^{\circ} \mathrm{F}$. Therefore, it is indicated that there was an advantage of using drying inlet temperature at $205{ }^{\circ} \mathrm{F}$ to produce tea with better liquoring properties when there is $60 \%$ good leaves. However, when there is only $40 \%$ good leaves, inlet temperature at $230{ }^{\circ} \mathrm{F}$ may increase the overall quality.

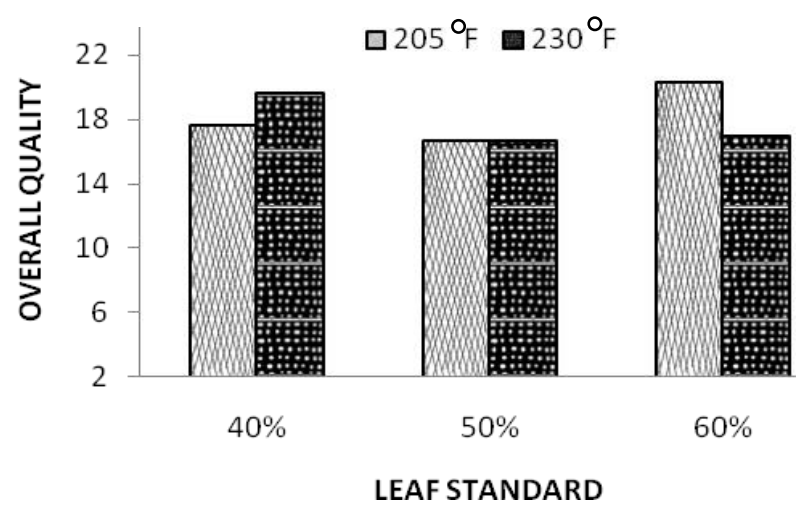

Figure 3. Overall qualities of OP grades at $205^{\circ} \mathrm{F}$ and $230{ }^{\circ} \mathrm{F}$ for three different leaf standards 
With respect to OP1 grade of $60 \%$ good leaves there was an increase in overall quality at $205{ }^{\circ} \mathrm{F}$ compared with $230{ }^{\circ} \mathrm{F}$ (Figure 4). Therefore, it is indicated that there was an advantage of using drying inlet temperature at $205{ }^{\circ} \mathrm{F}$ to produce tea with better liquoring properties when there is $60 \%$ good leaves.

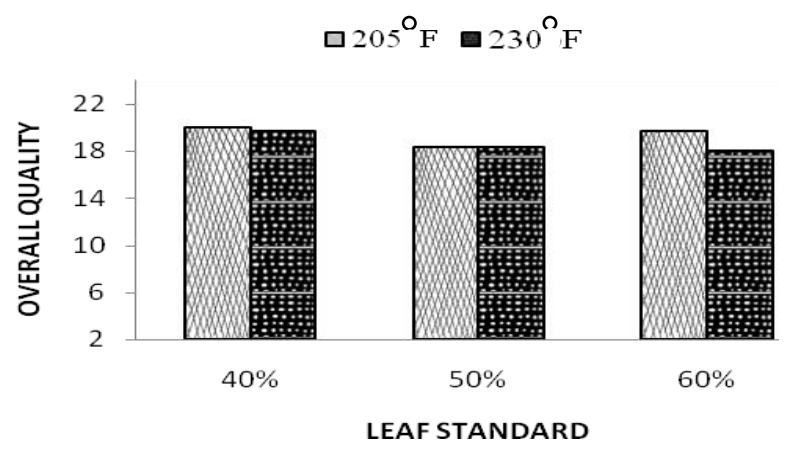

Figure 4. Overall qualities of OP1 grades at $205^{\circ} \mathrm{F}$ and $230{ }^{\circ} \mathrm{F}$ for three different leaf standards

No significant difference was observed for overall quality of PEKOE graded tea samples produced by treatment at $230{ }^{\circ} \mathrm{F}$ inlet temperature and control at $205{ }^{\circ} \mathrm{F}$ inlet temperature for three different leaf standards (Figure 5). However, in PEKOE grade of $60 \%$ good leaves, there was an increase in overall quality at $205{ }^{\circ} \mathrm{F}$ compared with $230{ }^{\circ} \mathrm{F}$. Therefore, it indicated that there was an advantage of using drying inlet temperature at $205{ }^{\circ} \mathrm{F}$ to produce PEKOE grade tea with better liquoring properties when there is $60 \%$ good leaves.

No significant difference was observed for overall quality of OPA graded tea samples produced by treatment at $230{ }^{\circ} \mathrm{F}$ inlet temperature and control at $205{ }^{\circ} \mathrm{F}$ inlet temperature for three different leaf standards (Figure 6). However, in OPA grade of $60 \%$ good leaves, there was an increase in overall quality at $205{ }^{\circ} \mathrm{F}$ compared with $230{ }^{\circ} \mathrm{F}$. Further, when there are 50\% good leaves, also there is also an increase in overall quality at $230{ }^{\circ} \mathrm{F}$ drying inlet temperature. 


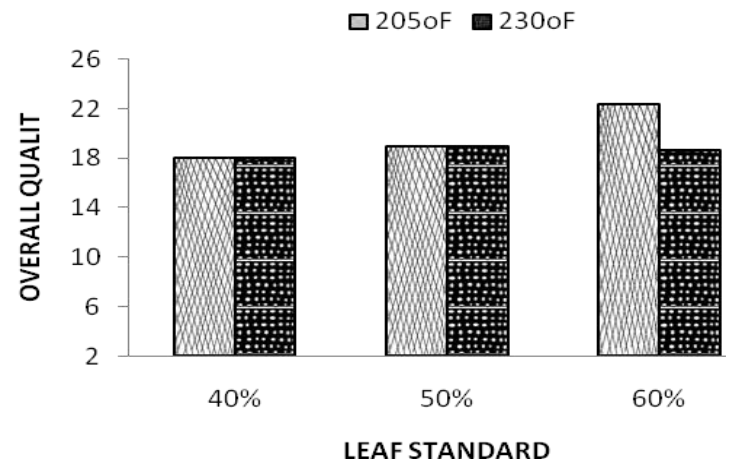

Figure 5. Overall qualities of PEKOE grades at $205^{\circ} \mathrm{F}$ and $230{ }^{\circ} \mathrm{F}$ for three different leaf standards

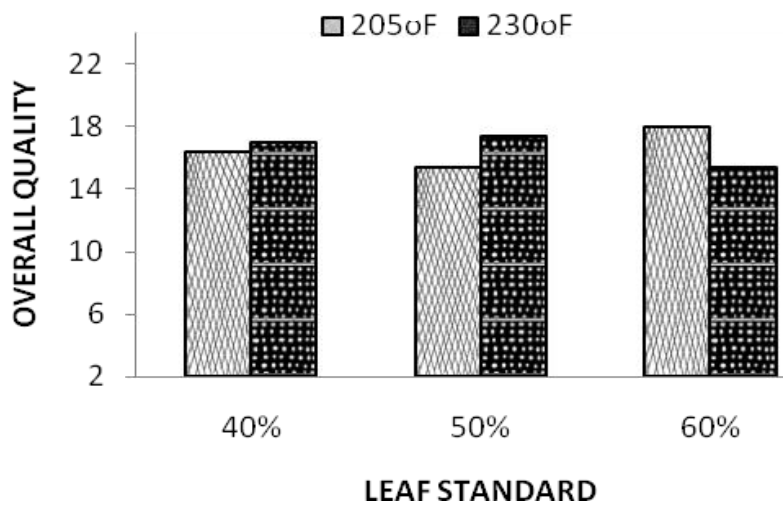

Figure 6. Overall qualities of OPA grades at $205^{\circ} \mathrm{F}$ and $230{ }^{\circ} \mathrm{F}$ for three different leaf standards.

No significant difference was observed for overall quality of FBOP graded tea samples produced by treatment at $230{ }^{\circ} \mathrm{F}$ inlet temperature and control at $205{ }^{\circ} \mathrm{F}$ inlet temperature for all three different leaf standards (Figure 7). However, in FBOP grade of $60 \%$ good leaves, there was an increase in overall quality at $205{ }^{\circ} \mathrm{F}$ compared with $230{ }^{\circ} \mathrm{F}$. Whereas, when there is $40 \%$ good leaves, overall quality may increase at drying inlet temperature of $230{ }^{\circ} \mathrm{F}$.

Results revealed that no significant difference was observed for overall quality of FBOPF1 graded tea samples produced by treatment 
at $230{ }^{\circ} \mathrm{F}$ inlet temperature and control at $205{ }^{\circ} \mathrm{F}$ inlet temperature for three different leaf standards (Figure 8). However, in FBOPF1 grade, there was an increase in overall quality at $205{ }^{\circ} \mathrm{F}$ compared with $230{ }^{\circ} \mathrm{F}$ for all three percentages $(60 \%, 50 \%$ and $40 \%)$ of good leaves.

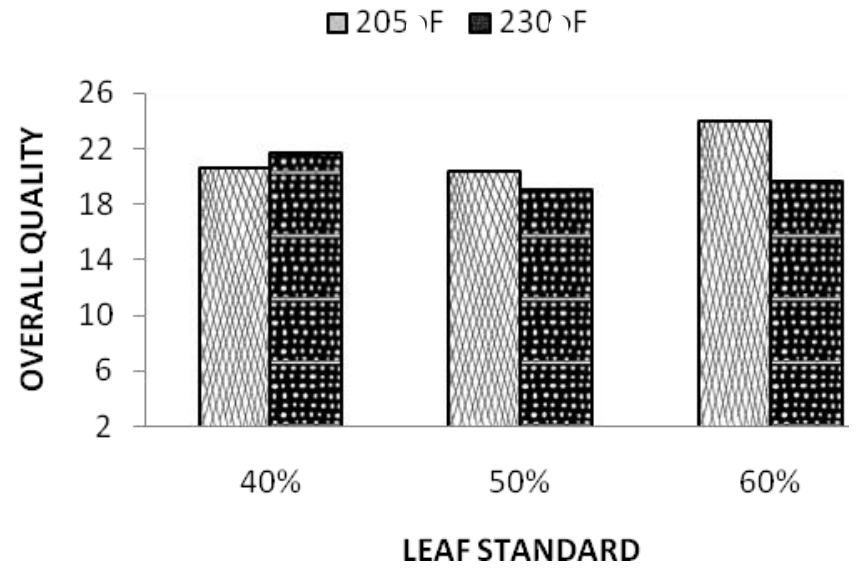

Figure 7. Overall qualities of FBOP grades at $205^{\circ} \mathrm{F}$ and $230{ }^{\circ} \mathrm{F}$ for three different leaf standards

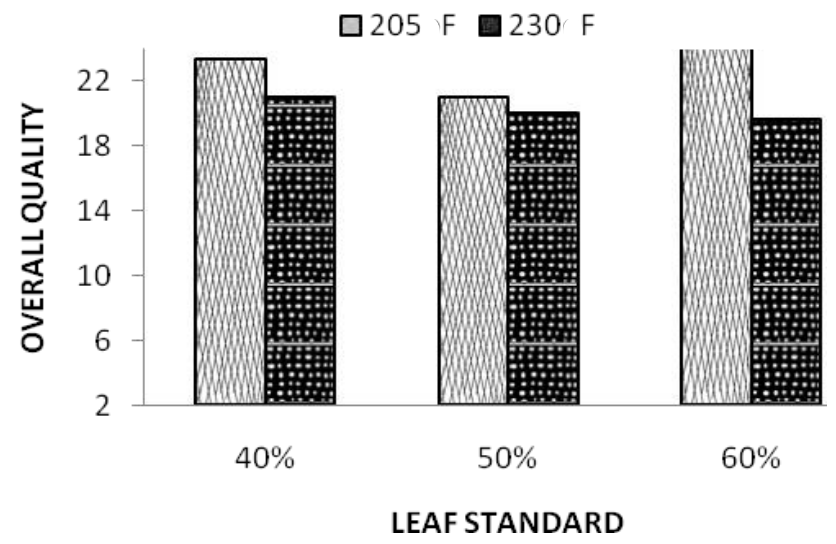

Figure 8. Overall qualities of $\mathrm{FBOPF} 1$ grades at $205{ }^{\circ} \mathrm{F}$ and $230{ }^{\circ} \mathrm{F}$ for three different leaf standards. 
According to the analysis of variance procedure, no significant difference was observed for overall quality (at the alpha level of 0.05) of FBOPF graded tea samples produced by treatment at $230{ }^{\circ} \mathrm{F}$ inlet temperature and control at $205{ }^{\circ} \mathrm{F}$ inlet temperature for three different leaf standards (Figure 9). However, in FBOBF grade of $60 \%$ leaf standard, there was an increase in overall quality at $205{ }^{\circ} \mathrm{F}$ compared with $230{ }^{\circ} \mathrm{F}$. Therefore, it indicated that there was an advantage of using drying inlet temperature at $205^{\circ} \mathrm{F}$ to produce tea with better liquoring properties when the leaf standard is $60 \%$ good leaves.

When all seven grades viz. OP, OP1, PEKOE, OPA, FBOP, FBOPF1, and FBOPF were considered, it was clearly shown that there was an advantage of using inlet temperature for drying at $205{ }^{\circ} \mathrm{F}$ in ECP dryer when the leaf standard is $60 \%$ of good leaves in pure Orthodox manufacture to achieve good overall quality of liquoring properties even though the treatments are not significant (Table 2).

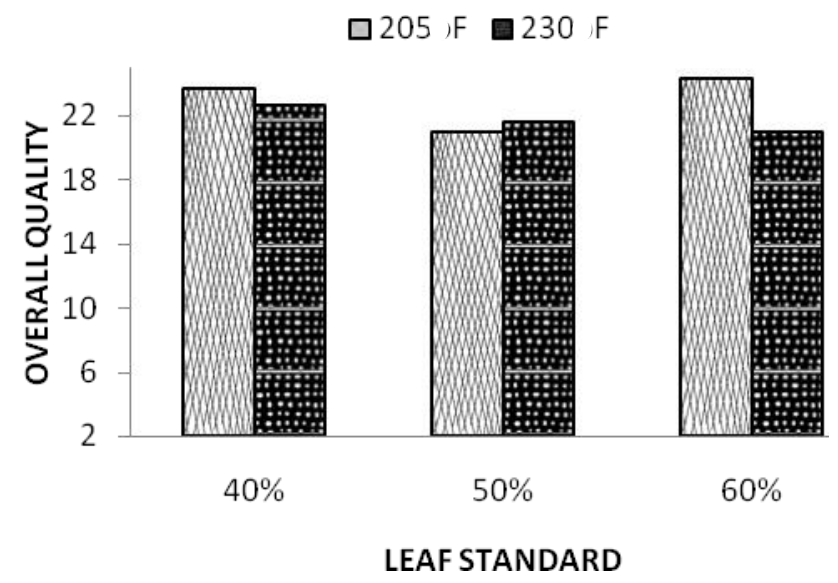

Figure 9. Overall qualities of FBOPF grades at $205^{\circ} \mathrm{F}$ and $230{ }^{\circ} \mathrm{F}$ for three different leaf standards 
Table 2. Mean values of overall qualities of seven different grades for treatment and control drying temperature for three different leaf standards (a) treatment combination, (b) Leaf Standard (\%)

\begin{tabular}{|c|c|c|c|c|c|c|c|c|c|}
\hline \multirow[t]{2}{*}{ (a) } & \multirow[t]{2}{*}{ (b) } & \multirow{2}{*}{$\begin{array}{c}\text { Temp } \\
\left({ }^{\circ} \mathrm{F}\right)\end{array}$} & \multicolumn{7}{|c|}{ Overall qualities of Grades } \\
\hline & & & OPA & OP & OP1 & PEKOE & FBOP & $\begin{array}{c}\text { FBOPF } \\
1\end{array}$ & FBOPF \\
\hline L1T1 & \multirow{2}{*}{40} & 205 & $16.3^{\mathrm{a}}$ & $17.6^{\mathrm{a}}$ & $20^{\mathrm{a}}$ & $18^{\mathrm{a}}$ & $20.7^{\mathrm{a}}$ & $23.3^{\mathrm{a}}$ & $23.7^{\mathrm{a}}$ \\
\hline L1T2 & & 230 & $17^{\mathrm{a}}$ & $19.7^{\mathrm{a}}$ & $19.6^{\mathrm{a}}$ & $18^{\mathrm{a}}$ & $21.6^{a}$ & $21^{a}$ & $22.7^{a}$ \\
\hline L2T1 & \multirow{2}{*}{50} & 205 & $15.3^{\mathrm{a}}$ & $16.6^{\mathrm{a}}$ & $18.3^{\mathrm{a}}$ & $19^{\mathrm{a}}$ & $20.3^{a}$ & $21^{a}$ & $21^{\mathrm{a}}$ \\
\hline L2T2 & & 230 & $17.3^{\mathrm{a}}$ & $16.7^{\mathrm{a}}$ & $18.3^{a}$ & $19^{a}$ & $19^{a}$ & $20^{a}$ & $21.7^{\mathrm{a}}$ \\
\hline L3T1 & \multirow{2}{*}{60} & 205 & $18^{a}$ & $20.3^{a}$ & $19.7^{\mathrm{a}}$ & $22.3^{\mathrm{a}}$ & $24^{a}$ & $25.3^{\mathrm{a}}$ & $24.3^{\mathrm{a}}$ \\
\hline L3T2 & & 230 & $15.3^{\mathrm{a}}$ & $17^{\mathrm{a}}$ & $18^{a}$ & $18.7^{\mathrm{a}}$ & $19.7^{\mathrm{a}}$ & $19.7^{\mathrm{a}}$ & $21^{\mathrm{a}}$ \\
\hline
\end{tabular}

Means with the same letter are not significantly different.

This is because the production of quality black tea depends on the concentration of chemical compounds in young and tender leaves. The chemical constituents of leaf are located in compartments or cells within the leaf. Also, leaf contains a group of proteins called enzymes. The enzymes are responsible for controlling all processes within the cell. One important enzyme for tea manufacture is the polyphenol oxidase which has the ability of reacting with the polyphenols present in leaf. The coarse leaves and stems have a low concentration of enzymes and chemical constituents compared to the tender leaves (Robert, 2008).

The quality of made tea depends on the presence of desirable compounds, undesirable compounds, and the feeling and sensitiveness of taste. The tea tasters evaluate the quality by a different number of parameters and they use different terms to express the quality (Wickramasinghe, 1978). However, biochemical ratio between thearubigin (TR) and theafavin (TF) is used to evaluate the quality of tea. The quality is mainly depends on two classes of substances called theafavin (TF) and thearubigin (TR). The taste is also associated with the oxidation process. The optimum fermentation condition is required for better taste by producing the correct combination of TR and TF. Under fermentation may 
contribute to the bitterness of the cup of tea due to unoxidized poly phenols. Over fermentation may hide the strength of the made tea.

\section{Appearance of made tea}

The appearance of seven graded made tea samples from treatment and control temperatures and three different leaf standards of $40 \%$, $50 \%$ and $60 \%$ of good leaves were evaluated by professional tasters by comparison. Samples were visually observed to determine the blackness from both higher inlet temperature and the control temperature.

Blackness of all graded tea samples manufactured from both $230{ }^{\circ} \mathrm{F}$ inlet temperature and $205{ }^{\circ} \mathrm{F}$ control temperature were analyzed by statistical analysis system ANOVA procedure followed by Duncan's Multiple Range Test ( $\mathrm{p}$ 0.05).

\section{- Analysis for PEKOE, OPA, FBOP and FBOPF grades}

Figure 10 shows the blackness of PEKOE grade. According to the graph, more blackness was received for higher inlet drying temperature of $230{ }^{\circ} \mathrm{F}$ for $40 \%$ and $60 \%$ good leaves standards compared to control temperature. The blackness of PEKOE grade tea produced at different temperature showed significant difference according to the analysis of variance (ANOVA).

According to the analysis of variance (ANOVA) procedure, there was a significant difference ( $\mathrm{P}$ value is smaller than 0.05 significance level $<0.0001$ ) among the mean blackness of OPA tea grade with respect to different inlet temperature combinations (Figure 11). More blacker in colour was received for $40 \%$ and $60 \%$ good leaves at higher inlet temperature $\left(230{ }^{\circ} \mathrm{F}\right)$. It indicated that higher inlet temperature $\left(230{ }^{\circ} \mathrm{F}\right)$ for $40 \%$ and $60 \%$ of good leaves produces a blacker appearance than control temperature $\left(205^{\circ} \mathrm{F}\right)$. 


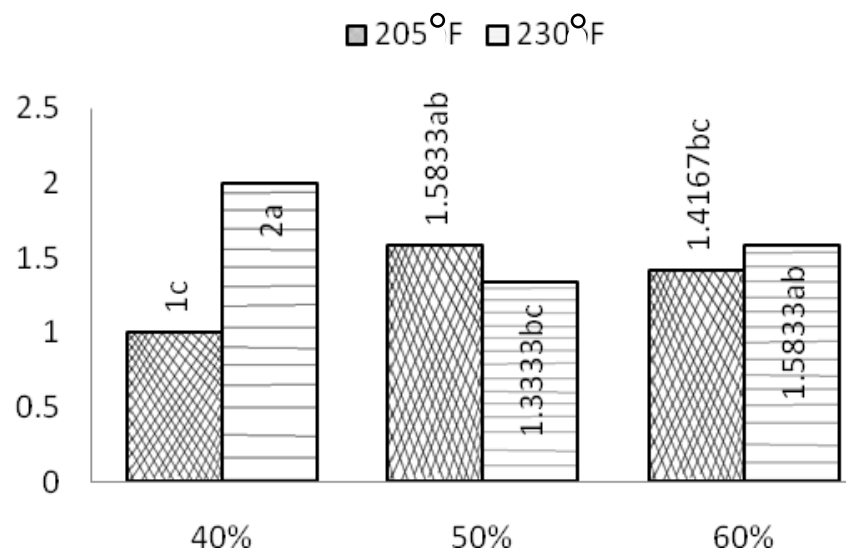

Figure 10. Overall blackness of PEKOE grades at $205^{\circ} \mathrm{F}$ and $230{ }^{\circ} \mathrm{F}$ for three different leaf standards (Means with different letters represent significant different at 5\% level)

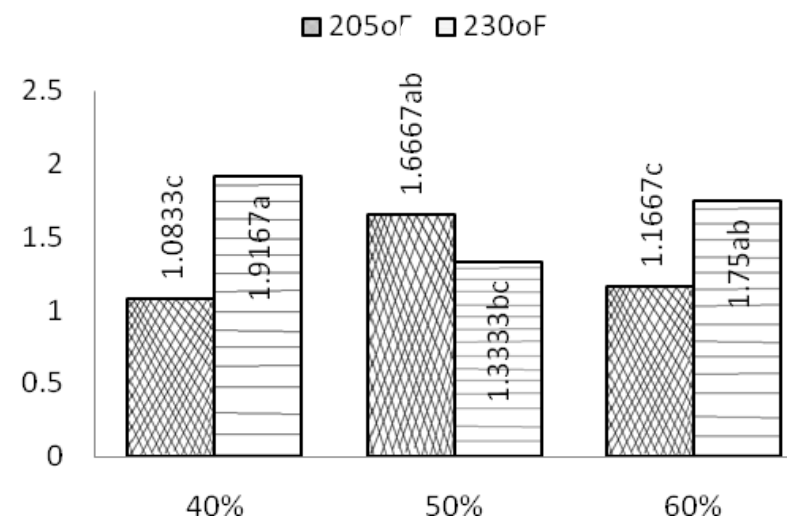

Figure 11. Overall blackness of OPA grades at $205{ }^{\circ} \mathrm{F}$ and $230{ }^{\circ} \mathrm{F}$ for three different leaf standards

The result indicated that there is a significant effect $(\mathrm{p}=0.0001)$ on blackness of FBOP grade with treatment combinations according to the analysis of variance (ANOVA) procedure. Both $40 \%$ and $60 \%$ of good leaves resulted more blackness at the higher inlet drying temperature $\left(230{ }^{\circ} \mathrm{F}\right)$ compared to control temperature $\left(205^{\circ} \mathrm{F}\right)$. Hence, there is no significant effect on $50 \%$ of good leaves from both temperature levels. 


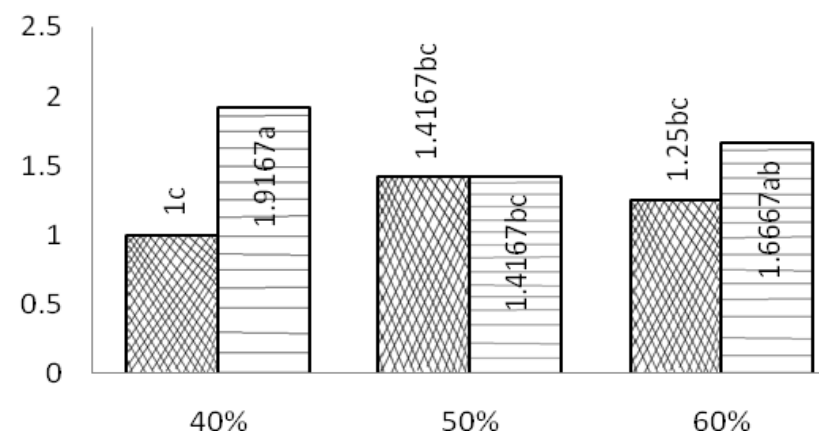

Figure 12. Overall blackness of FBOP grades at $205^{\circ} \mathrm{F}$ and $230{ }^{\circ} \mathrm{F}$ for three different leaf standards

Blackness of FBOPF tea grade significantly varied $(P=0.0001)$ with the different treatment means according to the analysis of variance (ANOVA). More blackness was received at higher inlet drying temperature $\left(230{ }^{\circ} \mathrm{F}\right)$ for $40 \%$ and $60 \%$ of good leaves (Figure 13). Therefore, higher inlet drying temperature for $40 \%$ and $60 \%$ of good leaves of FBOPF tea grade gives a blacker colour compared to control temperature.

\section{$\square 205$ oF $\square 230$ oF}

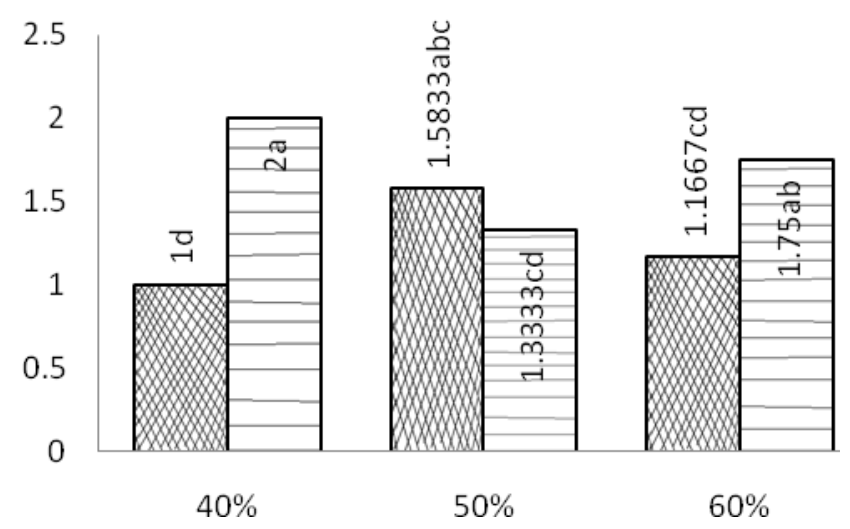

Figure 13. Overall blackness of FBOPF grades at $205^{\circ} \mathrm{F}$ and $230{ }^{\circ} \mathrm{F}$ for three different leaf standards 
The appearance of OPA, PEKOE, FBOP and FBOPF grades showed a significant difference in blackness when the leaf standard was $40 \%$ of good leaves at $230{ }^{\circ} \mathrm{F}$ inlet temperature (Figure 14).

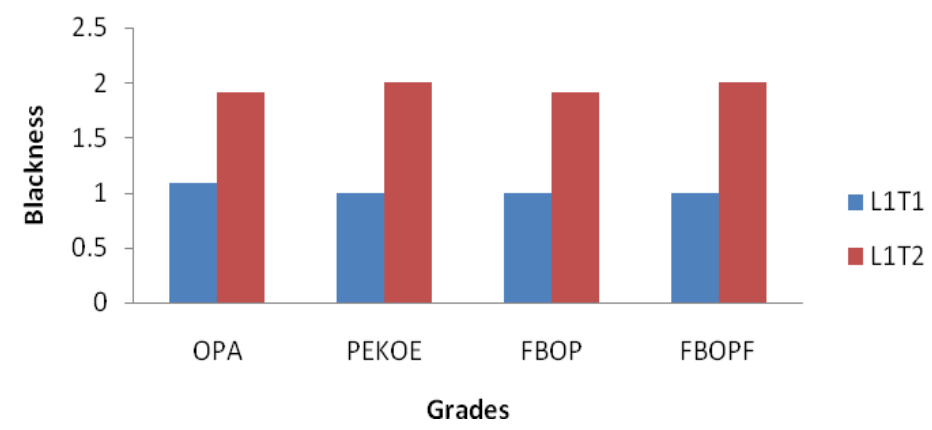

Figure 14. Overall appearances of OPA, PEKOE, FBOP, FBOPF grades at $40 \%$ of good leaves with $205^{\circ} \mathrm{F}$ and $230{ }^{\circ} \mathrm{F}$

\section{- Analysis for OP, OP1 and FBOPF1 grades}

According to the analysis of variance (ANOVA) procedure, there was no significant difference of appearance observed for the grades of OP, OP1 and FBOPF1 for different leaf standards and higher inlet drying temperatures (at the alpha level of 0.05). Therefore, it indicates that there was no appearance difference observed at the control and higher inlet drying temperature for the different grades.

\section{Conclusions and Recommendations}

Results revealed that there was no significant difference in liquoring properties of made tea produced at higher drying inlet temperature $\left(230{ }^{\circ} \mathrm{F}\right)$ when compared to $205{ }^{\circ} \mathrm{F}$ for the three different leaf standards of $40 \%, 50 \%$ and $60 \%$ of good leaves tested. Therefore, overall liquoring quality of made tea has no strong correlation between treatments according to the analysis. However, a trend was observed for tea produced using 60\% good leaves (leaf standard) which gave better liquoring properties at $205^{\circ} \mathrm{F}$ than the higher inlet temperature $\left(230^{\circ} \mathrm{F}\right)$. Therefore, when the leaf standard is good $(60 \%$ of good leaves), maintaining higher inlet temperature $\left(230{ }^{\circ} \mathrm{F}\right)$ for 
drying has not resulted in a specific advantage in relation to liquor quality. Therefore, it can be concluded that an effective way to reach the final quality of made tea by saving power and energy is to use the $205^{\circ} \mathrm{F}$ inlet drying temperature in the ECP dryer.

However, when the leaf standard is low, only $40 \%$ of good leaves using higher inlet drying temperature $\left(230{ }^{\circ} \mathrm{F}\right)$ will enhance the appearance or blackness in tea grades of OPA, PEKOE, FBOP and FBOPF. The appearance of OP, OP1 and FBOPF1 grades did not show a significant difference at higher inlet temperature in relation to all three leaf standards $(40 \%, 50 \%$ and $60 \%$ of good leaves). Therefore, a better appearance can be achieved by maintaining higher inlet drying temperature for leaf standard for only $40 \%$ of good leaves.

\section{References}

Botheju, W. S. (2001). Effect of plucking standard on profitability of made tea produced in Uva region, M Phil Thesis, University of Peradeniya.

Biswas., P. (2014). Sensing technology; current status and future trends II) pp 95-117

Jayaratnam, S. and D. Kirthisinghe, D. (1974). On the method of Orthodox manufacture and its effect on grade outturns and made tea characteristics 2 - The influence of hard rolling and high drying temperatures. Tea Q. 44(2 and 3) 132-143

Roberts, G. R. (2008). Principals of tea manufacture. Hand book on tea. pp $154-157$

Samaraweera D. S. A. and S. Ziyad, (2008). 'Technology of tea processing', Handbook on Tea, Tea Research Institute of Sri Lanka, pp 265 - 280 
Samaraweera, D. S. A. (1986). Technology of tea processing. Hand book on tea. Tea research institute of Sri Lanka (Eds.Sivapalan, P., Kulasegaram S. and Kathiravetpillai, A.) $158-207$.

Wickramasinghe, R. L. (1978). Monographs on tea production in Sri Lanka, Published by Tea Ressearch Institute of Sri Lanka. Pp 4 - 39

Received: 14-3-2016 Revised: 25-05-2016 Accepted: 29-06-2016 